\title{
STRATEGI LEMBAGA DAKWAH KAMPUS AL-JAMI' DALAM MEMBENTUK PEMAHAMAN AGAMA DI KALANGAN MAHASISWA
}

\author{
SYAHRU RAMADHAN \\ Program Pascasarjana Fakultas Dakwah dan Komunikasi \\ Universitas Islam Negeri (UIN) Alauddin Makassar \\ Email : syahruRMD@yahoo.com
}

\begin{abstract}
:
This paper discusses the al-Jami Campus Da'wah Institute strategy in shaping religious understanding among students, al-Jami Campus Da'wah Institute is the first intra-campus institution in the UIN Alauddin Makassar environment, as the central preaching in the campus environment until now, as for the objectives the establishment of this institution as a means to instill understanding of Islam in the form of the values of faith, worship and morals among students, over time the Campus Preaching Institutions that exist on campus have emerged, so that the existence of LDK al-Jami sometimes does not have an existence as a missionary institution on campus in preaching because of the many preaching institutions that have sprung up, both in the name of intra and extra-campus institutions, the preaching strategy undertaken by the campus missionary institution by using several patterns so that it can attract students to join and conduct ongoing coaching through mentors ing, general studies, and special studies. This paper tries to examine the pattern of coaching conducted by LDK al-Jami in preaching in the UIN Alauddin Makassar environment.
\end{abstract}

Keywords : Strategy, Religious Understanding, Al-Jami Campus Da'wah Institution

\section{PENDAHULUAN}

Agama merupakan realitas yang selalu menghiasi kehidupan manusia kehadiranya tidak hanya membawa dirinya sendiri. Agama melibatkan sesuatu yang berada di luar dari dirinya, sehingga agama memerlukan aspek lain yang selalu bersama yang secara substansial. Agama dan manusia merupakan sesuatu yang tidak dapat dipisahkan dalam kehidupan, bagaikan dua sisi mata uang yang saling melengkapi satu sama lain yang saling tarik menarik dan mempengaruhi serta memberikan ruang, sehingga agama akan bisa bermakna ketika manusia memberi makna, begitupun sebaliknya manusia bisa bermakna jika agama difungsikan dalam kehidupan. ${ }^{1}$

Pemberian makna terhadap agama yang dijabarkan dalam bentuk

${ }^{1}$ Arifuddin Ismail, Pemikiran dan Pemahaman Keagamaan Mahasiswa (Cet. I; Yogyakarta, Arti Bumi Intaran, 2015), h. 1. 
pemahaman agama maupun aktifitas keberagamaan itulah yang beragam. Banyaknya pemahaman keagamaan dalam berbagai bentuknya dapat terwakili oleh banyaknya bentuk pemahaman keagamaan dalam realitas kehidupan seharihari misalnya, radikal ${ }^{2}$, moderat ${ }^{3}$ dan liberal ${ }^{4}$ hadir disemua agama. Sejak hadirnya agama, pemahaman seperti ini akan terus ada dan akan tetap ada, pada dasarnya lahirnya berbagai macam pemahaman keagamaan baik dalam bentuk ideologi maupun gerakan yang ada disebabkan karena perbedaan latar belakang dan interpretasi terhadap teks agama yang berbeda sehingga dikaitkan dengan realitas kehidupan. ${ }^{5}$

Pemahaman keagamaan di Indonesia sudah mulai bermunculan sejak pasca orde lama yang digantikan oleh orde baru seiring dengan perubahan sistem politik yang dimulai dengan pemerintahan reformasi perubahan tersebut membawa pengaruh pada perkembangan kehidupan beragama, khusunya agama Islam. Mulai bermunculan berbagai macam aliran keagamaan, mulai dari pemikiran Islam rasional yakni pemikiran berorientasi pada paham kebebasan dalam beragama sampai pada paham agama yang moderat yang memilih jalur tengah antara rasional dan fundamental dengan kata lain tidak terlalu ke kiri dan tidak terlalu ke kanan, serta yang tekstual yakni pemahaman agama yang apa adanya dalam melihat teks agama, dari ketiga paham keagamaan tersebut yang saling mengklaim dan pengaruh di masyarat dan tidak jarang menimbulkan konflik di masyarakat. ${ }^{6}$

Salah satu gerakan modernisasi Islam yang berkembang di Indonesia adalah gerakan yang bercorak Islam murni yaitu salah satu kelompok yang menginginkan pada ajaran Islam yang murni yakni kembali pada al-Qur'an dan hadis Nabi Muhammad Saw, kelompok ini menginginkan ajaran Islam

${ }^{2}$ Fundamental merupakan sebuah paham yang menolak konsep modernisme dalam beragama mereka hanya berpegang teguh pada ajaran yang asli dalam beragama untuk menjaga kemurnian akan ajaran agamanya. Zainuddin, Pluralisme Agama dalam Analisis Kontruksi Sosial (Cet.II; Malang: UIN-Maliki Press, 2013), h. 86.

${ }^{3}$ Moderat sebuah paham yang tidak menitik beratkan pada pada ajaran yang tekstual dan tidak terlalu bebas dalam beragama akan tetapi paham ini mengambil sikap tengah dalam beragama menerima modernisme dan juga tidak menolak teks agama paham ini biasa juga disebut sebagai penengah antara paham liberalisme dan fundamentalisme. Zainuddin, Pluralisme Agama dalam Analisis Kontruksi Sosial (Cet. II, Malang: UIN-Maliki, Press, 2013), h. 84.

${ }^{4}$ Liberal merupakan paham yang menganut kebebasan, meyakini dan mengamalkan apa saja sesuai dengan kecenderungan masing-masing tanpa terikat oleh teks-teks agama, paham ini menekankan pada kebebasan individu dalam berpikir tanpa ada sesuatu yang lain yang membatasi. Abbudin Nata, Peta Keberagaman Pemikiran di Indonesia (Cet. II: Jakarta: PT Raja Grafindo Persada, 2001), h. 59.

${ }^{5}$ Arifuddin Ismail, Pemikiran dan Pemahaman Keagamaan Mahasiswa h. 2.

${ }^{6}$ Zainuddin, Pluralisme Agama dalam Analisis Kontruksi Sosial h. 4. 
dipraktekan dalam kehidupan sesuai dengan apa yang ada dalam al-Qur'an dan hadis tanpa melakukan penafsiran yang panjang, mereka menginginkan Islam yang murni sesuai tuntunan nabi saw dan salaf al-ṣhaleh yaitu sesuai dengan tiga generasi setelahnya yakni sahabat, tabi'in dan tabi'tabi;in, kelompok puritan Islam di Indonsia diwakili oleh ormas-ormas Islam seperti salafiyah (wahabiyah) ${ }^{7}, \mathrm{Hizb}$ al-Tahrir Indonesia, ${ }^{8}$ Majelis Mujahidin Indonesia (MMI) ${ }^{9}$, Wahdah Islamiyah dan Laskar Pembasmi Aliran Sesat (LAPAS) dan lainnya, semangat dakwah seperti ini sudah banyak dalam bentuk gerakan dakwah maupun dalam bentuk organisasi dakwah khsususnya pada bidang pendidikan sebagai basisi awal dalam membina umat, sehingga konsep dasar yang dibangun mulai dari tingkat sekolah menengah sampai pada level perguruan Tinggi.

Di beberapa Kampus khususnya Indonesia bagian Timur juga menjadi tempat para aktivis dakwah Kampus misalnya Universitas Hasanuddin, Universtas Muslim Indonesia dan berbagai Kampus lainnya yang menjadi pusat dakwah Kampus di bagian Timur Indonesia khususnya Sulawesi Selatan, perluasan aktifitas dakwah Kampus di kota Makassar sudah sampai pada perguruan tinggi Islam, seperti pada Kampus UIN Alauddin Makassar, sejak tahun 2006 berdiri sebagai Lembaga Dakwah Kampus dan menjadi salah satu lembaga internal di bawah naungan dengan aktifitas Lembaga Dakwah Kampus. Sehingga berdirinya lembaga ini sebagai sarana untuk meberikan kontribusi pemahaman Islam berupa nilai-nilai akidah, fiqh, ibadah serta akhlak di kalangan mahasiswa, dalam menambah nilai-nilai keIslaman pada mahasiswa justru lembaga memilki strategi tersendiri untuk menarik minat mahasiswa di antaranya dengan melalui dakwah,

${ }^{7}$ Salafi merupakan kelompok yang menjaga kemurnian ajaran Islam dari hal-hal yang berbau syirik bid'ah dan khurafat, al-Shabuni memberikan pendapat bahwa salafi merupakan sebuah kelompok yang menjaga ketat kemurnian aqidah Islam serta merealisasikan dalam kehidupan serta kayikinan. Andi Aderus, Aliran-Aliran Salafi di Tengah Aliran-Aliran Pemikiran KeIslaman (Cet. I; Jakarta: Kementrian Agama, 2001), h. 63.

${ }^{8}$ Hizbut al Tahrir Indonesia merupakan sebuah gerakan partai politik yang tidak masuk dalam partai politik di Indonesia akan tetapi kelompok ini merupakan sebuah gerakan yang menginginkan penerapan syariat Islam dalam daulah Islamiyah yang dipimpin oleh seorang pemimpin negara yang tidak memiliki batas teritorial yakni semua mencakup negara Islam yang dipimpin oleh seorang khalifah yang tidak memisahkan antara konsep kehidupan agama dan kosep kehidupan negara. Wakhid Sugiarto, Direktori Paham Keagamaan, Aliran, Dan Gerakan Paham Keagaan di Indonesia (Jakarta: Badan Litbang Kementrian Agama RI, Puslitbang Kehidupan Keagamaan, 2010), h. 218.

${ }^{9}$ Majelis Mujahidin Indonesia merupakan gerakan keagamaan yang menyuarakan jihad dan menginginkan penerapan syariat Islam di Indonesia melalui undang-undang, gerakan ini merupakan gerakan yang muncul akibat dari kondisi sosial-politik keagamaan di Indonesia sebagai implikasi dari ideologi yang bereka anut. Wakhid Sugiarto, Direktori Paham Keagamaan, Aliran, Dan Gerakan Paham Keagaan di Indonesia h. 220. 
fardiyah, kelompok serta, membuat kegiatan-kegiatan yang sifatnya umum serta sasarannya civitas akademika.

\section{TINJAUAN TEORITIS}

\section{Strategi Dakwah}

Strategi biasanya diistilahkan dengan pola atau cara yang dilakukan oleh seseorang yang memperoleh sesuatu, strategi dalam bahsa yunani disebut strategos yang merupakan perkembangan stratos (tentara) dan agein (pemimpin)istilah strategi digunakan oleh pemimpin militer untuk memengakan sebuah peperangan karena strategi merupakan langah atau cara dalam memenagkan peperangan, dalam hal ini strategi sudah banyak digunakan dalam kehidupan misalnya saja dalam koteks dakwah menggunakan kata strategi dakwah sebagai sarana dalam menyampaiakan syiar Islam. ${ }^{10}$

Sedangkan kata dakwah artinya memanggil, meyeru, atau mengajak dan isim failnya disebut da'i sebagai sebagai pelaku dakwah. ${ }^{11}$ Dakwah merupakan serangkaian aktivitas menyampaikan, meyeru serta mengajak orang lain dalam membina, serta belajar agama Islam sebagai sarana dalam terciptanya masyarakat Islam yang memahami serta mengamalkan ajaran Islam. ${ }^{12}$ Strategi dakwah merupakan langkah atau pola yang dilakukan untuk mencapai sasaran dakwah (Mad'u) untuk bisa memahami Islam dengan benar.

\section{Pemahaman Agama}

Pemahaman dalam bahasa Indonesia biasanya diartikan sebagai proses, perbuatan cara memahami dan memahamkan sesuatu ${ }^{13}$. pemahaman bukan hanya sekadar pada wilayah berpikir semata, akan tetapi meliputi aspek analisis terhadap sesuatu, menurut Bloom bahwa pemahaman mengkontruksi makna dari materi yang dipelajari baik yang bersifat lisan, tertulis maupun grafis. yang meliputi menafsirkan, mencotohkan, menyimpulkan membandingkan serta menjelaskan apa yang ditangkap dari objek tersebut. ${ }^{14}$ Pemahaman dalam kehidupan seharihari bisa dikatakan sebagai pengetahuan yang diperoleh dari sesuatu, sehingga seseorang bisa membandingkan dan menganalisis serta menafsirkan sesuatu baik

${ }^{10}$ Faridah, "Strategi Dakwah dalam Pembinaan Spiritual Narapidana di Lembaga Pemasyarakatan Wanita Kelas II A Sungguminahasa Gowa", Tesis (Program Pascasarjana: UIN Aluaddin Makassar, 2014), h.20.

${ }^{11}$ M. Munir dan Wahyu Ilahi, Manajemen Dakwah (Jakarta: Kencana, 2009), h. 17

${ }^{12}$ Moh. Ali Aziz, ilmu Dakwah (Cet. I Jakarta: Kencana, 2004), h. 11.

${ }^{13}$ Depatemen Pendidikan Nasional, Kamus Besar Bahasa Indonesia (Jakarta: Balai pustaka, 2005), h. 184.

${ }^{14}$ Faisal," Mengintegrasikan Revisis Taktonomi Blom ke dalam Pembelajaran Biologi”, Jurnal Sainsmat 4, no. 2, (2015): h. 104 
dalam pemaknaan terhadap objek dalam bentuk teoretis saja atau dalam bentuk tindakan sehingga membedakan dengan yang lain.

Makna agama secara umum diartikan tidak pergi atau tetap di tempat, diwarisi turun temurun, ${ }^{15}$ agama tetap berada ditempat (konsisten atau tidak berubah) dan tidak pergi, agama bisa dikatakan sebagai sebuah kepercayaan warisan dari nenek moyang sampai pada generasi sekarang. Menurut Harun Nasution bahwa kata agama disandingkan dengan kata religion atau religi yang berasal dari kata rilegere yang mengandung arti mengumpulkan dan membaca. Agama memang mengumpulkan atau cara-cara mengabdi kepada Tuhan, yang terkumpul dalam kitab suci-Nya yang harus dibaca. Dalam Islam istilah agama biasanya disebut sebagai al-dìn yang berarti kepercayaan yang dianut oleh seseorang atau juga bisa dikatakan sebagai ketaatan, menurut pendapat lain istilah ini juga berarti mengikat bagi manusia. yakni mengikat antara Tuhan dan manusia. $^{16}$

Jadi pemahaman agama yaitu sebuah bentuk pemaknaan akan ajaran agama yang dianutnya dalam kehidupan sehari-hari yang datang dari luar dirinya, baik itu sifatnya menyangkut teks agama, praktek ritual sesuai dengan pengetahuan akan agama yang dianutnya maupun menyangkut kehidupan dalam masyarakat sehingga yang membedakan dengan yang lainnya, sehingga membawa pada corak tersendiri dalam kehidupan beragama, maupun cara pandangnya terhap persoalan, baik dalam hal etika, cara beragama. Agama yang penulis maksudkan dalam tulisan ini yang agama Islam yang diyakini oleh mayoritas masyarakat di Indonesia.

\section{Lembaga Dakwah Kampus Al-Jami'}

Lembaga Dakwah Kampus al-Jami' merupakan lembaga internal Kampus yang kedudukannya sama dengan lembaga internal Kampus lainnnya, yang berkedudukan di bawah naungan yang secara legal barada pada ruang lingkup Universitas. Lembaga Dakwah Kampus merupakan lembaga yang telah berdiri selama kurang lebih 13 tahun pada Kampus UIN Alauddin Makassar, yang dideklarasikan pada tanggal 1 April pada masa jabatan Prof, Dr Azhar Arsyad, M.A, tahun 2005-2010 yang melegalkan berdirinya Lembaga Dakwah Kampus yang diprakarsai oleh Abdurrahman Faqih yang pada waktu itu menjabat sebagai Anggota Kesatuan Aksi Mahasiswa Muslim Indonesia (KAMMI) Komisariat UIN, pada awalnya kegiatan-kegiatan yang dilakukan hanya sifatnya keagamaan

${ }^{15}$ Harun Nasution, Islam di Tinjau dari Berbagai Aspeknya, Jilid I (Jakarta: Bulan Bintang 1974), h. 9.

${ }^{16}$ Harun Nasution, Islam di Tinjau dari Berbagai Aspeknya, Jilid I, h. 10. 
yang dilakukan oleh Kesatuan Aksi Mahasiswa Muslim Indonesia (KAMMI), sebagai organisasi ektra Kampus yang levelnya sama dengan oragnisasi Islam lainnya, yang berada di lingkungan Kampus dan diakui keberadaanya di Kampus. Namun tidak diakui secara legal dan diakui secara struktural dalam lingkungan Universitas sebagai organisasi intra Kampus. Organisasi KAMMI levelnya sama dengan HMI, PMII dan IMM. ${ }^{17}$

Lembaga Dakwah Kampus al-Jami' merupakan lembaga yang dibentuk oleh inisiatif dari para aktivis dakwah Kampus yang merindukan akan adanya lembaga dakwah yang sifatnnya internal dan dinaungi langsung oleh Lembaga Dakwah Kampus sehingga menjadi central bagi para mahasiwa, sebagai perekat dalam aspek membentuk pemahaman Islam di kalangan mahasiswa. Adapun hadirnya Lembaga Dakwah Kampus ini sebagai respon dari beberapa mahasiswa yang tergabung dalam KAMMI yang melihat kondisi mahasiswa pada waktu itu yang tidak lagi banyak menyentuh aspek agama. Moralnya sebagai mahasiswa Islam sudah menurun dan tidak ada bedannya dengan mahasiswa pada Kampus yang lainnya seprti Unhas dan UNM yang notabe kedua Kampus tersebut bukan Kampus yang berlabelkan Islam, maka dari itu dibentuknya Lembaga Dakwah Kampus itu sendiri bisa menjadi perekat bagi mahasiswa dalam lingkup UIN Alauddin Makassar untuk bisa memperbaiki akhlak dan lebih banyak mengetahui kewajibannya sebagai seorang muslim. ${ }^{18}$

Lembaga Dakwah Kampus al-Jami’ didirikan pada tanggal 1 April 2006 Lembaga Dakwah Kampus dideklarasikan oleh Rektor langsung pada hari itu juga dan jadikan sebagai lembaga tersendiri pada UIN Alauddin Makassar sebagai lembaga yang kehadirannya bagian dari pusat kegiatan mahasiswa. Deklarasi Lembaga Dakwah Kampus UIN Alauddin Makassar secara remi sebagai lembaga intra Kampus dihadiri oleh beberapa dari kalangan mahasisiwa dan beberapa dari organisasi intra Kampus yang ada, dan dihadiri oleh organisasi Islam seperti KAMMI, PMII, HMI dan IMM organisasi Islam yang besar di Kampus pada waktu itu. Peresmian organisasi ini dihadiri langsung beberapa tokoh yang ikut andil dalam meresmikan diantaranya Prof. Dr. Bahaking Rama dan Prof Dr. M. Natsir Siola. Dan Prof. Dr. Bahaking Rama sebagai Pembantu Rektor Bidang Kemahasiswaan selaku Pembina organisasi intra tingkat Universitas.

Perjalanan Lembaga Dakwah Kampus al-Jami' sampai sekarang sudah lewat satu dekade yakni 13 tahun keberadaanya di Kampus dan sudah 13 kali

\footnotetext{
${ }^{17}$ M. Faqih Faturrachman, (umur 34 tahun), Wiraswata PT. Gowa Creative(alumni LDK), wawancara, tanggal 19 Juli 2019 Juli 2019

${ }^{18}$ Khaidir (Umur 21 tahun), Ketua Umum LDK al-Jami', wawancara, Gowa, tanggal 6
} 
mengganti pengurus selama kurun waktu 2006-2019 dan sudah memiliki 4 lembaga dakwah tingkat Fakultas yang semuannya di bawah naungan Lembaga Dakwah Kampus al-Jami' ini menjadikan lembaga ini cukup berkembang pesat di bandingkan dengan lemabag internal lainnya pada tingkat universitas yang menghasilkan anak lembaga sebagai jalur koordinasi untuk mengembangkan sayap, lembaga dakwah tersebut ada pada Fakultas Tarbiyah dan keguruan dengan anama LDF al-Uswah, LDF al-Islah pada Fakultas Syariah dan Hukum, LDF Ulil al-Bab pada Fakultas Sains dan teknologi dan LDF Ar-Rahmah pada Fakultas UShuluddin, Filsafat dan politik

\section{PEMBAHASAN}

\section{Strategi Lembaga Dakwah Kampus Al-Jami' Dalam Membentuk Pemahaman Agama Di Kalangan Mahasiswa}

Hasil penelitian menunjukan bahwa strategi Dakwah Lembaga Dakwah Kampus dalam membentuk pemahaman agama di kalangan mahasiswa yang dilakukan oleh Lembaga Dakwah Kampus al-Jami' yaitu dengan dua cara yaitu dengan dakwah langsung secara pribadi atau dengan dakwah perorangan dakwah fardiyah $^{19}$ dan dakwah dalam pembinaan.

Adapun tujuan dari dakwah fardiyah yaitu untuk lebih dekat sehingga adanya kedekatan emosional sehingga lebih mudah dalam berkomunikasi antara sesama mahasiswa dengan sasaran dakwah, dalam konsep ini diharapkan adalah untuk mengenalkan Lembaga Dakwah Kampus terhadap mahasiswa UIN Alauddin Makassar sehingga mereka tertarik untuk bergabung pada Lembaga Dakwah Kampus al-Jami.

Aktifitas yang dilakukan oleh Lembaga Dakwah Kampus sendiri dalam mengenalkan program Lembaga Dakwah Kampus antara lain dengan program WTC welcome to campus yaitu berpartisipasi dalam penyambutan MABA di antaranya menjadi relawan MABA, seminar dan sekolah minat dan bakat, sebagai wadah pembentukan skill bagi para mahasiswa ${ }^{20}$.

Kegiatan tersebut merupakan langkah awal yang dilakukan oleh Lembaga Dakwah Kampus al-Jami' untuk memperkenalkan Lembaga Dakwah Kampus alJami' kepada para mahasiswa, baik secara personal maupun dalam bentuk kegiatan seminar dan even tertentu serta memberikan pemahaman kepada para mahasiswa tentang Lembaga Dakwah Kampus al-Jami', pada bagian ini

${ }^{19}$ Dakwah fardiyah merupakan dakwah yang dilakukan secara individu kepada objek dakwah tujuannya ialah untuk lebih membangun hubungan emosioal terhadap objek dakwah itu sendiri sehingga yang diharapkan adalah kedekatan antar individu.

${ }^{20}$ Fadhil Asy’ari Ahmadin, (umur 22 tahun), Koordinator Kaderisasi Ikhwan, wawancara, Gowa, tanggal, tanggal 5 Juli 2019. 
pengenalan Lembaga Dakwah Kampus secara umum serta kegiatan-kegiatan yang dilakukan oleh Lembaga Dakwah Kampus al-Jami, sehingga objek dakwah tertarik dan igin bergabung pada Lembaga Dakwah Kampus al-Jami'.

Straetgi dakwah yang dilakukan oleh Lembaga Dakwah Kampus alJami'dalam membentuk pemahaman agama di antaranya yaitu:

\section{Rekrutment}

Rekruitmen merupakan proses dalam Kaderisasi Lembaga Dakwah Kampus al-Jami untuk bisa bergabung dalam Lembaga Dakwah Kampus al-Jami' dan merupakan proses awal membentuk pemahaman agama dikalangan masisiwa yang tergabung dalam Lembaga Dakwah Kampus, rekrutment biasanya dilakukan untuk membentuk pemahaman seorang kader tentang Islam dan untuk membedakan dengan yang lain tentang pemahaman agama. berbeda tingkatan dalam LDK al-Jami berbeda juga dari pemahaman agama yang dimiliki, adapun tingkatan dalam kekaderan Lembaga Dakwah Kampus yaitu kader mula, kader muda dan kader madya. Kader muda adalah seseorang yang telah mengikuti proses rekruitmen tingkat satu yaitu Super Islamic Camp (SIC), kader muda adalah seseorang yang telah mengikuti Super Islamic Camp Power (SICP) dan kader madya adalah kader yang telah melewati Training Muslim Kafah (TMK).

Adapun tujuan yang ingin dicapai dalam rekriutmen yaitu Super Islamic Camp (SIC) yaitu terbentuknya pemahaman agama Islam yang benar, dan pemahaman tentang pentingnya Lembaga Dakwah Kampus al-Jami' dalam menyebarkan Islam di Kampus UIN Alaudddin Makassar. Kegiatan tersebut diikuti oleh para mahasiswa yang akan bergabung dalam Lembaga Dakwah Kampus al-Jami' dan biasanya materi yang disampaikan hanya yang berkaitan dengan Aqidah ibadah serta pengenalan Lembaga Dakwah Kampus sebagaimana yang dikatakan oleh Sitti Rahmah.

Materi Super Islamic Camp (SIC) pada Lembaga Dakwah Kampus alJami' meliputi aqidah, ibadah dan mu'amalah dari ketiga cakupan ini digabung semua dalam kurikulum rekriutman tingkat 1 sehingga yang menjadi tujuan utama adalah peserta dapat memahami tentang Islam. ${ }^{21}$

Pada tahap ini para anggota dibina dari segi pemahaman tentang dasardasar Islam berorganisasi serta kepemimpinan, serta dari segi ibadah misalnnya di wajibkan bagi para anggota kader untuk sholat lail sebagai bentuk pembiasaan diri pada peserta untuk melakukan ibadah, paling tidak melakukan amalan-amalan sunah dan baca al-Qur'an, karena biasanya para anggota Lembaga Dakwah

\footnotetext{
${ }^{21}$ Sitti Rahma, (umur 21 tahun), Koordinator Kaderisasi Akhwat, wawancara, tanggal 09
} Juli 2019. 
Kampus banyak yang bukan berasal dari latar belakang pesantren, sehingga banyak di antara para peserta mengikuti Lembaga Dakwah Kampus hanya karena ingin lebih dalam mempelajari Islam maka dari itu kegiatan tersebut ditanamkan pengetahuan akan dasar-dasar Islam melaui materi-materi rekriutment di antaranya Syumuliatul Islam, kepemimpinan, Amal Jama'I, Problematika Umat dan keLDKan. Sehingga semua materi-materi terangkum tentang pemahaman tentang Lembaga Dakwah Kampus, pemahan Islam dan ibadah.

Super Islamic Camp Power (SICP) tahap ini dilakukan oleh anggota aktif Lembaga Dakwah Kampus al-Jami' untuk lebih meningkatkan pemahaman tentang Lembaga Dakwah Kampus akan tetapi tidak semua kader aktif bisa mengikuti tahap ini, yang bisa ikut tahap ini hanya mereka yang terjaring oleh Murabbi seorang mentor yang menilai anggota kader yang layak ikut dalam tahapan yang kedua ini, sehingga tahapan yang kedua sudah masuk pada tataran bentuk pengaplikasian terhadap konsepsi Islam akan pemahaman tentang kerjakerja dakwah. Tahapan yang ketiga Training Muslim Kaffah tahapan ini diikuti oleh mahasiswa yang sudah alumni atau pasca Kampus model tahapan ini dalam proses kegiatnnya tidak sama dengan bentuk pertama dan kedua akan tetapi dimbing langsung oleh Pembina. Pemahaman pada tingkat yang ketiga ini bukan lagi pada implementasi tentang konsep dakwah yang didapatkan pada lemabag dakwah Kampus akan tetapi sudah bisa menyusun strategi dakwah dan konsep berpikir yang mumpuni akan persoalan yang ada baik pada bidang agama maupun bidang politik sehingga kosep yang ketiga ini sudah mulai berpikir tentang konsep politik. $^{22}$

Dari ketiga tingkatan kader di atas berdasarkan bentuk training yang dilakukan baik pada tingkat mula, muda dan madya semuannya merupakan salah satu bentuk pembinaan pemahaman agama dan kelembagaan yang tergabung dalam Lembaga Dakwah Kampus al-Jami’ sehingga kader Lembaga Dakwah Kampus al-Jami' tingkat pemahaman Islamnnya bisa dilihat dari sejauh mana tingkatan kekaderannya atau partisipasinnya serta lamannya mereka berproses pada Lembaga Dakwah Kampus al-Jami'. Pada intinya bahwa training yang dilakukan oleh Lembaga Dakwah Kampus dilakukan untuk lebih meningkatkan pengetahuan tentang dasar-dasar Islam secara umum. Namun pada intinya bahwa kegiatan tersebut merupakan tahap awal dalam memperkenalkan Islam di kalangan mahasiswa, walaupun LDK al-Jami’ sendiri berdiri pada institusi Islam

${ }^{22}$ Fadhil Asy'ari Ahmadin, (umur 22 tahun), Koordinator Kaderisasi Ikhwan, wawancara, Gowa, tanggal, tanggal 5 Juli. 
bukan berarti semua yang masuk pada UIN Alauddin Makassar paham tentang ajaran Islam secara menyeluruh, maka dari itu perlu adanya Lembaga Dakwah Kampus yang mengakomodir sebagai lembaga dakwah yang bisa memfasilitasi tentang pemahaman Islam di kalangan mahasiswa.

\section{Mentoring}

Salah satu strategi dakwah Lembaga Dakwah Kampus al-Jami' adalah mentoring. Mentoring merupakan proses pembinaan pemahaman agama dalam bentuk kelompok, pada Lembaga Dakwah Kampus al-Jami' bagi para mahasiswa yang telah mengikuti training tingkat pertama Super Islamic Camp, atau yang sudah masuk pada kader tingkat mula sehingga setelah mengikuti training tersebut seorang kader wajib mengikuti mentoring atau biasanya diistilahkan dengan sebutan tarbiyyah maupun liqo.' Namun pada intinya kedua nama tersebut sama yaitu bentuk pembinaan agama berkelompok sebagai kelanjutan dari training tingkat satu.

Dalam pembinaan model ini para anggota kader lembaga dibagi ke dalam bentuk group kajian, untuk memasifkan dakwah dalam membentuk pemahaman agama para anggota group, dibagi 5-12 orang serta dipegang oleh 1 orang mentor sebagai pembimbing untuk mengajarkan tentang aqidah, aklak dan ibadah, yang merupakan tujuan yang harus dicapai oleh seorang anggota mentoring yang masuk dalam anggota Lembaga Dakwah Kampus al-Jami' sebagai sarana dalam membentuk pemahaman Islam, kurikulum yang diberikan kepada Muttarabi bagi yang pertama kali masuk dalam Lembaga Dakwah Kampus. Yaitu perbaikan dari aspek pengetahuannnya tentang cara membaca al-Qur'an, setelah keduannya sudah dianggap cukup, maka tahap selanjutnya adalah pemberian materi kepada para muttarabi tarbiyyah untuk diberikan pemahaman tentang materi Aqidah Islam, akhlak dan juga ibadah sebagai pembentukan pemahaman agama Islam bagi para mahasiswa, sebagai bekal untuk menyebarkan Islam. Adapun materimateri yang digunakan mengacu pada super mentoring dan buku-buku mentoring yang ada. ${ }^{23}$

Dalam pembinaan tersebut banyak aspek yang diperhatikan yaitu dari segi ibadah harian dan pengamalan-pengamalan sunah dan dievaluasi sehingga bisa memberikan motivasi bagi para peserta tarbiyyah untuk memperbaiki diri dan juga memberikan tugas. serta output dari dakwah itu sendiri, sehingga kadang kala para peserta diberikan kesempatan beriskusi tentang problem dan tantangan dalam melakukan dakwah Islamiyyah sehingga para anggota liqo' tidak jenuh,

\footnotetext{
${ }^{23}$ Sitti Rahma, (umur 21 tahun), Koordinator Kaderisasi Akhwat, wawancara, tanggal 09
} Juli 2019. 
yang menjadi inti dari mentoring adalah bagaiamana para anggota kader bisa saling ta'ruf, tafahum dan ta'awun dalam menjalin ukhuwah Islamiyah baik sesama anggota lembaga dan mahasiswa secara umum.

Pada intinya semua strategi dakwah yang dilakukan oleh Lembaga Dakwah Kampus ada di Lembaga Dakwah Kampus umumnya lebih banyak berpengaruh dalam membentuk menanamkan pemahaman agama, di kalangan mahasiswa yaitu pada Proses mentoring, karena semua materi tentang keIslaman baik pada aspek teori, praktek dan problem solving tentang keIslaman semuannya di dapatkan pada program mentoring. Maka dari itu banyak mahasiswa yang tergabung pada Lembaga Dakwah Kampus al-Jami mulai belajar tentang keIslaman masuk pada LDK al-Jami' sehingga banyak anggota Lembaga Dakwah Kampus yang terpola akan pemahaman Islamnya lewat mentoring ini karena pelajaran agama yang dilakukan pada Lembaga Dakwah Kampus khususnya mentoring adalah bertahap sehingga memungkinkan banyak anggotannya bertahan dalam lingkungan tarbiyyah dan biasanya sangat membantu dalam memecahkan masalah.

\section{Taskif}

Taskif merupakan pembinaan agama yang dilakukan oleh Lembaga Dakwah Kampus yang sifatnya internal lembaga atau tertutup bagi mahasiswa yang lain, sehingga kegiatan ini hanya diikuti oleh mahasiswa yang tergabung dan menjadi pengurus Lembaga Dakwah Kampus al-Jami,' tujuan dari program pembinaan ini yaitu untuk lebih menguatkan para anggota Lembaga Dakwah Kampus al-Jami' bagaimana seorang kader dakwah memiliki pemahaman agama yang kaffah,. Dalam tahapan ini semua muatan materi yang digunakan dalam materi pembinaan sudah sistematis mengikuti buku panduan dan materi kepengurusan yang belum selesai. Sebagai yang diungkapkan oleh Siti Rahmah:

Program taskif ini dilakukan oleh Lembaga Dakwah Kampus untuk menguatkan kader yang bersifat lembaga dan aspek evaluasi, kegiatan ini dilakukan 3 kali dalam satu pekan. Yang bertanggung jawab dalam pembinaan ini adalah bidang kaderisasi sebagai pengontrol, adapun materimatri yang ada, sifatnnya tematik yaitu sudah tersusun mengikuti buku Syarah Arkanul Ba'iah (10 pilar penopang kejayaan dakwah) yang dikarang oleh Yusuf Qardhawi. Atau materi dari pengurus sebelumnya, akan tetapi kami dalam periode ini menggunakan syarah arkanul ba'iah karangan Yusuf Qardhawi sebagai judul-judul materi taskif karena tidak jauh berbeda 
materi-materinya dengan yang diberikan oleh pengurus sebelumnya. ${ }^{24}$

Pembinaan tersebut merupakan kegiatan yang diikuti oleh semua kader dakwah Kampus yang memiliki afiliasi dengan UKM Lembaga Dakwah Kampus al-Jami' sehingga semua perserta yang hadir merupakan kader aktif dan pengurus lembaga dakwah internal Kampus baik itu Lembaga Dakwah Kampus al-Jami' maupun empat lembaga dakwah Fakultas yang ada, sehingga bisa memberikan pemahaman agama kepada para anggota Lembaga Dakwah Kampus yang ada. Begitu pula dengan pemantik yang diundang untuk menyampaikan materi kajian yang merupakan kader alumni atau seseorang yang sehaluan dengan Lembaga Dakwah Kampus al-Jami', sehingga kosep dan pemahaman akan Lembaga Dakwah Kampus sendiri tidak keluar dari materi yang dibahas. Taskif sendiri merupakan penguatan pada pemahaman agama lembaga anggota internal Lembaga Dakwah Kampus al-Jami.

\section{Ta'lim}

Ta'lim merupakan salah satu sarana untuk menanamkan pemahaman agama pada mahasiswa secara umum yang dilakukan oleh Lembaga Dakwah Kampus satu kali satu pekan, sebagai salah satu program kerja Lembaga Dakwah Kampus untuk menyiarkan Islam lewat sebuah forum kajian yang diisi oleh seorang ustadz, baik ustadz yang alumni dari Lembaga Dakwah Kampus maupun dari dosen UIN Alauddin Makassar, sasaran dari program ini adalah mahasiswa secara umum, baik dari kalangan mahasiswa lama maupun mahasiswa baru, sebagai sasaran dakwah pada Lembaga Dakwah Kampus al-Jami', sehingga materi-materi yang disampaiakan disesuaikan dengan isu atau trend yang sedang berkembang.

Ta'lim merupakan kajian yang bersifat umum yang tujuan untuk menanamkan pemahaman agama kepada para mahsiswa secara umum, sebagai sarana untuk belajar Islam bagi para mahasiswa berbagai tingkatan, baik yang masih mahasiswa baru maupun yang sudah alumni. Dan biasanya kajian umum dilakukan di Masjid Kampus al-Jami', adapun materi-materi yang di sampaikan pun beragam, mengikuti momentum yang ada, baik itu berisfat agama, politik maupun dari ibadah keseharian. Pematerinya pun menyesuaikan dengan kapasitas seorang pemantik atau pemateri kajian,

Ta'lim merupakan strategi Lembaga Dakwah Kampus al-Jami kepada para mahsiswa UIN Alauddin Makassar sebagai tahap membina pemahaman agama dikalangan mahasiwa dan kadangkala banyak para anggota yang bergabung pada

\footnotetext{
${ }^{24}$ Sitti Rahma, (umur 21 tahun), Koordinator Kaderisasi Akhwat, wawancara, tanggal 09
} Juli 2019. 
Lembaga Dakwah Kampus al-Jami' berawal dari mengikuti ta'lim, jadi Lembaga Dakwah Kampus al-Jami' disamping membuat kegiatan yang sifatnya untuk menambah wawasan pengetahuan agama juga melibatkan mahasiswa yang lain untuk saling menyebarkan kebaikan.

Dari keempat starategi dakwah yang dilakukan oleh Lembaga Dakwah Kampus al-Jami' dalam membentuk pemahaman agama mahasiswa dikalangan mahasiswa yaitu dengan dakwah perorangan dan dakwah berkelompok yaitu membina pemahaman agama dalam bentuk organisasi dan pembinaan dalam bentuk kajian umum sehingga strategi dakwah dalam bentuk organisasi yaitu membina dari aspek akidah, ibadah dan akhlak dalam mentoring dan rekrutmen sehingga menjadi muslim yang kaffah dalam memahami Islam, dalam taklim merupakan pembentukan pemahaman Islam secara umum yang tidak berkesinambungan sehingga tidak memberikan pemahaman yang utuh karena terputus disebabkan tidak memiliki kosep materi yang tersusun.

\section{SIMPULAN}

Strategi dakwah Lembaga Dakwah Kampus al-Jami menggunakan beberapa pola dalam menanamkan pemahaman Islam di kalangan mahasiswa. Sesuai dengan konsep kekinian yang tidak keluar dari beberapa konsep dakwah diantaranya dakwah bi al-lisan, dakwah bi al-mau'izah, dakwah bi al-hikmah, dan dakwah bi al-hasanah dan bi al-jadal. Dari semua kosep dakwah yang ada sesuai dalam al-Qur'an surah al- nahl ayat 125, sudah tercover dalam pola pembinaan pemahaman Islam di kalangan mahasiswa pada lembaga dakwah kampus al-Jami' melaui rekriutment, mentoring, taskif serta talim, pembinaan yang dilakukan oleh lembaga dakwah Kampus secara berkesinambungan sampai pada pemahaman Islam yang kaffah.

\section{DAFTAR PUSTAKA}

Ismail, Arifuddin. 2015. Pemikiran dan Pemahaman Keagamaan Mahasiswa. Yogyakarta, Arti Bumi Intaran,

Zainuddin. 2013. Pluralisme Agama dalam Analisis Kontruksi Sosial. Malang: UIN-Maliki Press.

Nata, Abbudin. 2001. Peta Keberagaman Pemikiran di Indonesia. Jakarta: PT Raja Grafindo Persada.

Aderus, Andi. 2001. Aliran-Aliran Salafi di Tengah Aliran-Aliran Pemikiran KeIslaman. Jakarta: Kementrian Agama. 
Wakhid Sugiarto. 2010. Direktori Paham Keagamaan, Aliran, Dan Gerakan Paham Keagaan di Indonesia. Jakarta: Badan Litbang Kementrian Agama RI, Puslitbang Kehidupan Keagamaan.

Depatemen Pendidikan Nasional, 2005. Kamus Besar Bahasa Indonesia. Jakarta: Balai Pustaka.

Faisal," Mengintegrasikan Revisis Taktonomi Blom ke dalam Pembelajaran Biologi”, Jurnal Sainsmat 4, no. 2, (2015): h. 104

Harun Nasution, 1974. Islam di Tinjau dari Berbagai Aspeknya, Jilid I. Jakarta: Bulan Bintang.

Faridah. 2014. "Strategi Dakwah dalam Pembinaan Spiritual Narapidana di Lembaga Pemasyarakatan Wanita Kelas II A Sungguminahasa Gowa", Tesis (Program Pascasarjana: UIN Aluaddin Makassar. 